\title{
CYTOTOXIC ACTIVITY OF ALKALOID EXTRACTS OF DIFFERENT PLANTS AGAINST BREAST CANCER CELL LINE
}

FARAH A Al-MARZOOK, RABAB OMRAN*

Department of Biology, College of Science, University of Babylon, Iraq. Email: omranaljelawi@gmail.com

Received: 28 February 2017, Revised and Accepted: 13 April 2017

\begin{abstract}
Objectives: To study in vitro cytotoxic activity of total alkaloid extracts of Pinus sabiniana L., Phoenix dactylifera L. and Ferocactus sp. L. against breast cancer cell line Michigan Cancer Foundation-7 (MCF-7) and non-tumorigenic fetal hepatic cell line (WRL-68).

Methods: Plant powder of each P. sabiniana L. leaves, P. dactylifera L. pollen grains, and Ferocactus sp. L. The leaves were extracted separately with $80 \%$ methanol, chloroform at $\mathrm{pH} 2$ and $\mathrm{pH} 10$ and the chloroform portion was dried to obtain the total alkaloid extracts. The total alkaloids were detected qualitatively by Mayer's, Dragendorff's and Hager's reagents and estimated quantitatively by bromocresol green spectrophotometry depending on the atropine calibration curve. The cytotoxic activity was evaluated by 3-[4, 5-dimethylthiazoyl]-2, 5-diphenyltetrazolium bromide assay.

Results: The extract of $P$. sabiniana L. had highest total alkaloid content $(164.62 \pm 2.8 \mathrm{mg} / 100 \mathrm{~g}$ dry weight of plant) than the other plants. The total alkaloids of Ferocactus sp. L. and P. dactylifera L., reduced the cell viability of both cell lines, the highest reduction occurred in the concentration $400 \mu \mathrm{g} / \mathrm{ml}$ was $46 \pm 2.20 \%$ (MCF-7) and 56.2 $\pm 2.2 \%$ (WRL-68) for Ferocactus sp. L., followed by 56.2 $\pm 2.2 \%$ (MCF-7) and 57.5 $\pm 3.2 \%$ (WRL-68) for $P$. dactylifera L. The alkaloids of P. sabiniana was very lower effects on both cell lines MCF-7, and WRL-68 was $89.3 \pm 3.44 \%$ and $90.16 \pm 2.7 \%$, respectively, at the same concentration.
\end{abstract}

Conclusion: Plant alkaloids had variable effects against cancer and normal cell lines depending on the type of alkaloid compounds and their concentration in the extract.

Keywords: Alkaloids, Pinus sabiniana, Phoenix dactylifera, Ferocactus sp., In vitro, Cytotoxicity, Breast cancer.

(C) 2017 The Authors. Published by Innovare Academic Sciences Pvt Ltd. This is an open access article under the CC BY license (http://creativecommons. org/licenses/by/4. 0/) DOI: http://dx.doi.org/10.22159/ajpcr.2017.v10i7.18189

\section{INTRODUCTION}

Cancer is one of the most life-threatening diseases and possesses many health hazards in both developed and developing characterized by irregular proliferation of cells. The toxicity of chemotherapeutic drugs sometimes creates a significant problem in the treatment of cancer using allopathy or established medicine. Plants still have enormous potential to provide newer drugs and as such are a reservoir of natural chemicals that may provide chemoprotective potential against cancer [1]. Recently, various therapies have been propounded for the treatment of cancer, many of which use plant-derived products. The medicines always played an important role in the global health. The health medicinal plants providing a new area of drug research [2]. The demand for plant-based medicines, food supplement, health products, pharmaceuticals, and cosmetics are increasing in both developing and developed countries due to the growing recognition that then a natural products are non-toxic, have less side effects and easily available [3]. Secondary metabolites have been developed in nature form of different plant species, insects, fungi, algae, and prokaryotes during evolution in enormous diversity. Plant secondary metabolites can be defined as the compounds that play an important role in the interaction of the plant with its environment, but have no such role in maintaining the fundamental life processes in plants [4]. The alkaloids represent a group of natural products that has had a major impact throughout history on the economic, medical, political, and social affairs of humans. Many of these agents have potent physiological effects on mammalian systems as well as other organisms, and as a consequence, some constitute important therapeutic agents [5]. In fact, alkaloids are among the most important active components in plants, and some of these compounds have already been successfully developed into chemotherapeutic drugs, such as camptothecin, a famous topoisomerase I inhibitor [6], and vinblastine, which interacts with tubulin [7]. Several alkaloids exhibit significant biological activities, such as the relieving action of ephedrine for asthma, the analgesic action of morphine, and the anticancer effects of vinblastine $[7,8]$. The objective of our study was to investigate the cytotoxic activity of total alkaloid extracts of three plants, including Pinus sabiniana L., Phoenix dactylifera L., and Ferocactus sp L. against breast cancer cell line Michigan Cancer Foundation-7 (MCF-7) and non-tumorigenic fetal hepatic cell line (WRL-68).

\section{MATERIALS AND METHODS}

\section{Plants collection}

The plants $(P$. sabiniana L. leaves, $P$. dactylifera pollen grain, Ferocactus sp. L. leaves) were collected from the gardens of University of Babylon, Hilla, Iraq, during March 2015. The plant parts were washed with tap water to remove dust and then with distilled water (DW), and dried under shade for 10 days at room temperature. Each dried part was ground and stored in airtight container to prevent the humidity effect and then stored at room temperature until further use.

\section{Total alkaloid extraction}

Total alkaloids were extracted according to Harborne [9]. Briefly, $20 \mathrm{~g}$ of plant dry powder was extracted with $80 \%$ methanol for $24 \mathrm{~h}$ in a continuous extraction by Soxhlet apparatus $250 \mathrm{ml}$ volume. The extract was filtered by Whatman No.1 filter paper and then, the filtrate was concentrated by a rotary evaporator under vacuum at $45^{\circ} \mathrm{C}$ until the solution reached to $10 \mathrm{ml}$. Subsequently, the concentrated extract was transferred to a separating funnel and $2 \mathrm{~N} \mathrm{HCl}$ was added gradually to adjust the $\mathrm{pH}$ value up to 2 , after that the extract was washed with $10 \mathrm{ml}$ chloroform three times. Then, the $\mathrm{pH}$ value of the extract was adjusted to 10 using $\mathrm{NH}_{4} \mathrm{OH}$, and partitioned with $10 \mathrm{ml}$ chloroform three times. The chloroform portion was dried to obtain the total alkaloid extract. 
The dried extract was weighed, and preserved in a clean container at $4^{\circ} \mathrm{C}$ for further investigation.

\section{Qualitative detection of alkaloids}

To detect the presence of alkaloids in plant extracts some qualitative tests were performed using Mayer's, Dragendorff's and Hager's reagents. Mayer's reagent used to screen all types of alkaloids, prepared by dissolving $13.5 \mathrm{~g}$ of mercuric chloride and $5 \mathrm{~g}$ of $\mathrm{KI}$ in $1000 \mathrm{ml}$ distilled water. The test was done by adding $1-2 \mathrm{ml}$ of the reagent to $5 \mathrm{ml}$ of plant extract. The formation of white or creamy precipitate indicated the test was positive [10]. Furthermore, Dragendorff's reagent was used to investigate alkaloids in plant extract. The reagent was prepared by dissolving $20 \mathrm{~g}$ of bismuth nitrate in $40 \mathrm{ml}$ distilled water and $16 \mathrm{~g}$ of sodium iodide in $40 \mathrm{ml}$ distilled water, then, the two solutions were mixed. The test was performed by adding 1-2 $\mathrm{ml}$ of Dragendorff's reagent in $5 \mathrm{ml}$ of the plant extract, the formation of a prominent orange color indicated the test was positive [11]. Hager's test was done by adding a few drops of the reagent to plant extracts and appeared a yellow-colored precipitate that indicates the presence of alkaloids. Hager's reagent is saturated solution of picric acid [12].

\section{Estimation of total alkaloid content}

The total alkaloid content was estimated by bromocresol green (BCG) spectrophotometry method $[13,14]$. The BCG reagent was prepared by heating $69.8 \mathrm{mg}$ of BCG with $3 \mathrm{ml}$ of $2 \mathrm{~N} \mathrm{NaOH}$ and $5 \mathrm{ml}$ distilled water until completely dissolved and then, the solution was diluted to $1000 \mathrm{ml}$ with distilled water. Phosphate buffer solution $(\mathrm{pH} 4.7)$ was prepared by adjusting the $\mathrm{pH}$ of $2 \mathrm{M}$ sodium phosphate $\left(71.6 \mathrm{~g} \mathrm{Na}_{2} \mathrm{HPO}_{4}\right.$ in $1 \mathrm{l}$ distilled water) to 4.7 with $0.2 \mathrm{M}$ citric acid (42.02 g citric acid in $1 \mathrm{l}$ distilled water).

\section{BCG assay}

A $10 \mathrm{mg}$ of the plant extract was dissolved in $2 \mathrm{~N} \mathrm{HCl}$ and then filtered. This solution $(1 \mathrm{ml})$ was transferred to separatory funnel and washed with $10 \mathrm{ml}$ chloroform (3 times). The $\mathrm{pH}$ of the extract was adjusted to neutral with $0.1 \mathrm{~N} \mathrm{NaOH}$. Then, $5 \mathrm{ml}$ of BCG solution and $5 \mathrm{ml}$ of phosphate buffer were added to the extract. The mixture was shaken, and the complex was extracted with 1,2,3, and $4 \mathrm{ml}$ chloroform by vigorous shaking, the extract was then collected in a $10 \mathrm{ml}$ volumetric flask and diluted with chloroform. The absorbance of the complex in chloroform was measured at $470 \mathrm{~nm}$ against blank prepared as above but without alkaloid (plant extract) [14]. The total alkaloids were calculated depending on the calibration curve of atropine.

The standard curve was constructed using $(0.4,0.8,1.2,1.6$, and $2 \mathrm{ml})$ of atropine standard solution $(1 \mathrm{mg} / 10 \mathrm{ml})$ and each of them was transferred to different separating funnels as the previous method. The absorbance of the complex in chloroform was measured at $470 \mathrm{~nm}$ against blank prepared as above but without atropine [13].

\section{Cytotoxic activity}

To determine the cytotoxic activity against two kinds of cell linesincluding breast cancer cell line MCF-7 and non-mutagenic fetal hepatocyte WRL-68 using 3-[4,5-dimethylthiazoyl]-2, 5-diphenyltetrazolium bromide (MTT dye). Briefly, $100 \mu \mathrm{l}$ cell suspension was added to the flat-bottomed micro-culture plate wells, separated plate for each cell line in triplicate, and treated them with $100 \mu \mathrm{l}$ partially purified plant extract, incubated for $24 \mathrm{~h}$, centrifuged to remove the dead cells. Aliquot of $100 \mu \mathrm{l}$ of $2 \mathrm{mg} / \mathrm{ml}$ MTT dye was added to each well, and the incubation was continued for a further $4 \mathrm{~h}$, then $50 \mu \mathrm{l}$ of solubilization solution of dimethyl sulfoxide was added to each well. After complete solubilization of the dye, the absorbance was read at $620 \mathrm{~nm}$ with an enzyme-linked immunosorbent assay reader. The mean absorbance for each group of replicates was calculated. The percentage viability of cells exposed to various treatments was calculated as follows [15]:

$$
\% \text { Cell viability }=\frac{\text { Mean absorbance of treated sample }}{\text { Mean absorbance of non-treated sample }} \times 100
$$

The control was the non-treated cultures in all experiments that contained cells in the medium only. This assay was held at the Centre for Natural Product Research and Drug Discovery, Department of Pharmacology, Faculty of Medicine, University of Malaya/Kuala Lumpur, Malaysia.

\section{Statistical analysis}

Statistical analysis of the data was performed using SPSS 14.0 version using one-way analysis of variance according to the method described by Levesque [16] numerical data were expressed as mean \pm standard deviation. $p<0.05$ was considered to be statistically significant.

\section{RESULTS}

The qualitative analysis of all extracts appears the presence of alkaloids by changing the color in each regent. The quantitative contents of alkaloid compounds were estimated according to bromocresol green (BCG) spectrophotometry method [13,14], and the total alkaloids were calculated depending on the calibration curve of atropine (Fig. 1). Tables 1 and 2 show the total alkaloid contents, which revealed the highest concentration of alkaloids in P. sabiniana leaves were $164.62 \pm 2.80 \mathrm{mg} / 100 \mathrm{~g}$ DW and $P$. dactylifera pollen grains were $66.50 \pm 2.00 \mathrm{mg} / 100 \mathrm{~g}$ DW, while the Ferocactus sp. leaves were $50.37 \pm 2.50 \mathrm{mg} / 100 \mathrm{~g}$ DW. The results of cell viability assay based on the MTT assay using MCF-7 and WRL-68 cell lines which treated with total alkaloid extracts appeared the percentage of cytotoxicity increased with increasing concentration of alkaloids. The Ferocactus sp. and P. dactylifera L. alkaloid extracts had cytotoxicity effect on both cancer and normal cell as shown in Tables 3 and 4. The highest reduction of viability was observed at the highest concentration $(400 \mu \mathrm{g} / \mathrm{ml})$ of Ferocactus sp. alkaloid extract was $46.87 \pm 1.80 \%$ and $56.20 \pm 2.20 \%$ for the breast cancer and normal cell lines, respectively (Table 3), whereas P. dactylifera alkaloid extract reduced the cell viability to $56.20 \pm 2.20 \%$ for breast cancer cell line and $57.50 \pm 3.20 \%$ for normal cell line (Table 4). While P. sabiniana alkaloid extract had less effects on both cell lines were $89.30 \pm 3.44 \%$ and $90.16 \pm 2.70 \%$ for cancer and normal cells, respectively, at $400 \mu \mathrm{g} / \mathrm{ml}$ (Table 5).

\section{DISCUSSION}

The quantitative contents of alkaloid compounds showed different concentrations among three plants, the highest concentration of alkaloids was $P$. sabiniana leaves, and the less concentration was Ferocactus sp. leaves., P. dactylifera pollen grains also had alkaloids. These results were in agreement with Al-Samarai et al. [17] how found the alkaloid concentration in P. dactylifera pollen grains were higher than another phytochemical compound. The range of alkaloid concentration necessary to elicit the anticancer effects is wide $[6,7,18]$, and not all alkaloids can react with BCG dye [14]. Therefore, due to the lack of a general method to estimate all types of alkaloids [19], the method described in this study can be used for the determination

Table 1: Qualitative detection of alkaloids in plant extract using different reagent

\begin{tabular}{lll}
\hline Reagent & Result & Resulted color \\
\hline Mayer's reagent & + & Creamy precipitate \\
Dragendorff's reagent & + & Orange color \\
Hager's test & + & Yellow color \\
\hline
\end{tabular}

Table 2: The total alkaloid contents of tested plant

\begin{tabular}{lllll}
\hline Plant & Family & $\begin{array}{l}\text { Common } \\
\text { name }\end{array}$ & $\begin{array}{l}\text { Part } \\
\text { used }\end{array}$ & $\begin{array}{l}\text { Amount in mg/100 g } \\
\text { of plant DW } \mathbf{S D}\end{array}$ \\
\hline $\begin{array}{l}\text { Ferocactus } \\
\text { sp. }\end{array}$ & Cactaceae & $\begin{array}{l}\text { Glaucous } \\
\text { barrel cactus }\end{array}$ & Leaves & $50.37 \pm 2.50$ \\
$\begin{array}{l}\text { Pinus } \\
\text { sabiniana }\end{array}$ & Pinaceae & Aleppo pine & Leaves & $164.62 \pm 2.80$ \\
$\begin{array}{l}\text { Phoenix } \\
\text { dactylifera }\end{array}$ & Arecaceae & Date palm & Pollen & $66.50 \pm 2.00$ \\
\hline
\end{tabular}

DW: Distilled water, SD: Standard deviation 
Table 3: Cytotoxic activity of the total alkaloids of Ferocactus sp. L. against the breast cancer cell line MCF7 and normal cell line WRL-68

\begin{tabular}{llll}
\hline Alkaloid extract concentration $\boldsymbol{\mu g} / \mathbf{m l}$ & \% Viability of WRL \pm SD & \% Viability of MCF7 \pm SD & IC $_{\mathbf{5 0}}$ of MCF7 $\boldsymbol{\mu g} / \mathbf{m l}$ \\
\hline 400 & $54.68 \pm 0.78$ & $46.87 \pm 1.80$ & $5.091 \mathrm{e}+006$ \\
200 & $84.36 \pm 1.30$ & $77.79 \pm 1.20$ & \\
100 & $86.60 \pm 2.00$ & $89.24 \pm 5.00$ & \\
50 & $91.49 \pm 0.70$ & $94.32 \pm 3.50$ & \\
\hline
\end{tabular}

MCF-7: Michigan Cancer Foundation-7, SD: Standard deviation, $\mathrm{IC}_{50}$ : Inhibitory concentration

Table 4: Cytotoxic activity of the total alkaloids of $P$. dactylifera $L$. pollen grains against the breast cancer cell line MCF7 and normal cell line WRL-68

\begin{tabular}{|c|c|c|c|}
\hline Alkaloid extract concentration $\mu \mathrm{g} / \mathrm{ml}$ & $\%$ Viability of WRL \pm SD & $\%$ Viability of MCF-7 \pm SD & $\mathrm{IC}_{50}$ of MCF-7 $\mu \mathrm{g} / \mathrm{ml}$ \\
\hline 400 & $57.50 \pm 3.20$ & $56.20 \pm 2.20$ & $2.094 \mathrm{e}+006$ \\
\hline 200 & $87.68 \pm 3.70$ & $82.60 \pm 2.67$ & \\
\hline 100 & $94.30 \pm 2.20$ & $86.40 \pm 3.19$ & \\
\hline 50 & $93.70 \pm 2.12$ & $90.70 \pm 6.20$ & \\
\hline
\end{tabular}

P. sabiniana: Pinus sabiniana, MCF-7: Michigan Cancer Foundation-7, SD: Standard deviation, $\mathrm{IC}_{50}$ : Inhibitory concentration

Table 5: Cytotoxic activity of the total alkaloids of $P$. sabiniana L. leaves against the breast cancer cell line MCF7 and normal cell line WRL-68

\begin{tabular}{lll}
\hline Alkaloid extract concentration $\boldsymbol{\mu g} / \mathbf{m l}$ & \% Viability of WRL $\mathbf{S S D}$ & \% Viability of MCF-7 \pm SD \\
\hline 400 & $90.16 \pm 2.70$ & $89.30 \pm 3.44$ \\
200 & $91.74 \pm 1.00$ & $92.10 \pm 2.33$ \\
100 & $92.78 \pm 0.65$ & $93.80 \pm 2.92$ \\
50 & $94.50 \pm 3.23$ & $95.50 \pm 2.57$ \\
\hline
\end{tabular}

P. sabiniana: Pinus sabiniana, MCF-7: Michigan Cancer Foundation-7, SD: Standard deviation, $\mathrm{IC}_{50}$ : Inhibitory concentration

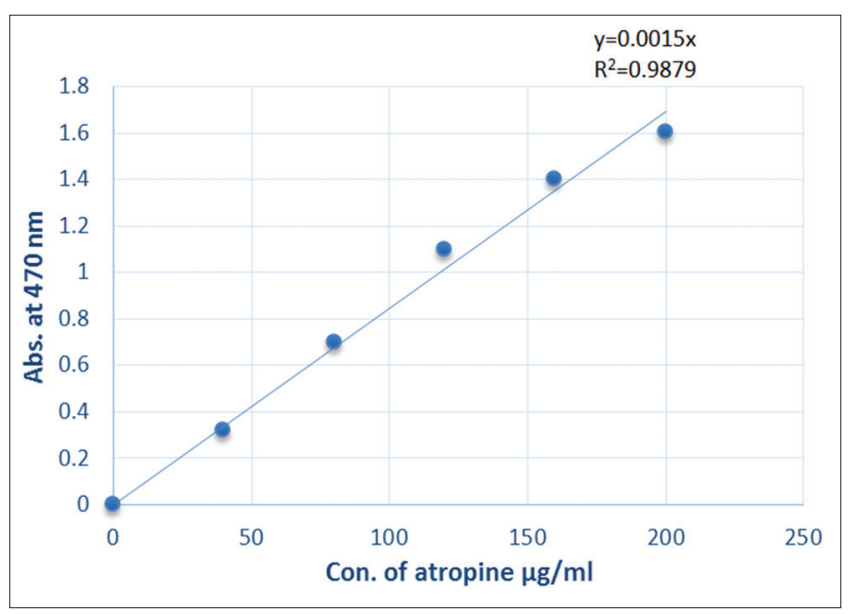

Fig. 1: Calibration curve of the atropine using bromocresol green methods at $470 \mathrm{~nm}$

of a special group of alkaloids [13,20,21]. The BCG can react with a certain class of alkaloids, and some alkaloids do not react with this reagent $[14,22]$.

The alkaloids of Ferocactus sp. leaves and $P$. dactylifera pollen grains had an anticancer activity to reduce the growth of cancer cell; also, it had inhibited effect on normal cell. The compounds that inhibit cancer initiation are traditionally termed (blocking agents), this bioactive component present in plants can prevent carcinogenesis by blocking metabolic activation, increasing detoxification, or providing alternative targets for electrophonic metabolites [23]. They may act by preventing the interaction between chemical carcinogens or endogenous free radicals and DNA, thereby reducing the level of damage and resulting mutations which contribute not only to cancer initiation but also progressive genomic instability and overall neoplastic transformation. Protection may be achieved as a consequence of decreased cellular uptake and metabolic activation of procarcinogens and/or enhanced detoxification of reactive electrophiles and free radical scavenging, as well as induction of repair pathways [24-26]. This activity of inhibition may be due to the nature of the compounds found in each crude extract and their interaction with metabolic nature of each type of cancer cells or may be due to the effectiveness of some enzymes that act as antioxidants especially in cancer cells $[27,28]$. Alkaloid extract of Ferocactus sp. and P. dactylifera may be contained another phytochemical compounds having effect on normal cell lead to reduce the viability, alkaloids isolated from natural herbs are not always safe have side effect lead to the toxicity [29], such as Neurotoxicity, immunotoxicity, and reproductive toxicity induced by piperine have been reported [18,30,31], and hepatotoxicity and embryonic toxicity can also be induced by sanguinarine $[32,33]$. The present study indicates that the chloroform alkaloid extract of P. sabiniana had slightly effect on the cell viability of both cell lines. In the other words, it had not anti-cancer activity against MCF-7.

\section{CONCLUSION}

Plant alkaloids had variable effects against cancer and normal cell lines depending on the type of alkaloid compounds and their concentration in the extract. Furthermore, these alkaloids need to further purification and tested against different cell lines to determine their effectiveness.

\section{REFERENCES}

1. Izevbigie EB. Discovery of water-soluble anticancer agents (edotides) from a vegetable found in Benin City, Nigeria. Exp Biol Med (Maywood) 2003;228(3):293-8.

2. Desai AG1, Qazi GN, Ganju RK, El-Tamer M, Singh J, Saxena AK, et al. Medicinal plants and cancer chemoprevention. Curr Drug Metab 2008;9:581-91.

3. Verma N, Jha K, Chaudhary S, Singh O, Kumar A. Phytochemistry, pharmacology and traditional uses of Leptadenia pyrotechnica - An important medicinal plant. Indian J Pharm Biol Res 2014;2(1):128-34.

4. Oksman-Caldentey KM, Inzé D. Plant cell factories in the post-genomic era: New ways to produce designer secondary metabolites. Trends Plant Sci 2004;9(9):433-40

5. Capasso A, Aquino R, Tommasi ND, Piacente S, Rastrelli L, Pizza C. Neuropharmacology activity of alkaloids from South American medicinal plants. Curr Medi Chem CNS Agents 2002;2:1-15. 
6. Huang M, Gao H, Chen Y. Chimmitecan, a novel 9-substituted camptothecin, with improved anticancer pharmacologic profiles in vitro and in vivo. J Clin Cancer Res 2007;13(4):1298-307.

7. Li W, Shao Y, Hu L, Zhang X, Chen Y, Tong L, et al. BM6, a new semisynthetic vinca alkaloid, exhibits its potent in vivo anti-tumor activities via its high binding affinity for tubulin and improved pharmacokinetic profiles. J Cancer Biol Ther 2007;6(5):787-94.

8. Benyhe S. Morphine, new aspects in the study of an ancient compound. Life Sci 1994;55:969-79.

9. Harbone JB. Phytochemical methods. A Guide to Modern Techniques of Plant Analysis. $2^{\text {nd }}$ ed. London: Chapman and Hall; 1984. p. 307.

10. Harborne JB. Phytochemical Methods. $2^{\text {nd }}$ ed. New York: Chapman and Hall; 1984. p. 288.

11. Antherden LM. Text Book of Pharmaceutical Chemistry. $8^{\text {th }}$ ed. London: Oxford University Press; 1969. p. 813-4

12. Neelima N, Gajanan N, Sudhakar M, Kiran V. A preliminary phytochemical investigation on the leaves of Solanum xanthocarpum. Int J Res Ayurveda Pharm 2011;2(3):845-50.

13. Shamsa F, MonsefH, Ghamooshi R, Verdian-Rizi M. Spectrophotometric determination of total alkaloids in some Iranian medicinal plants. Thai J Pharm Sci 2008;32:17-20.

14. Amanlou M, Khosravian P, Effat S, Akbari HM. Determination of buprenorphine in raw material and pharmaceutical products using ionpair formation. Bull Korean Chem Soc 2007;28(2):183-90.

15. Liu CP, Tsai WJ, Lin YL, Liao JF, Chen CF, Kuo YC. The extracts from Nelumbo Nucifera suppress cell cycle progression, cytokine genes expression, and cell proliferation in human peripheral blood mononuclear cells. Life Sci 2004;75(6):699-16.

16. Levesque R, SPSS. Programming and Data Management: A Guide for SPSS and SAS Users. $4^{\text {th }}$ ed. Chicago: SPSS Inc.; 2007.

17. Al-Samarai AH, Al-Salihi FG, Al-Samarai RR. Phytochemical constituents and nutrient evaluation of date palm (Phoenix dactylifera, L.) Pollen grains. Tikrit J Pure Sci 2016;21(1):56-62.

18. Sun Y, Xun K, Wang Y, Chen X. A systematic review of the anticancer properties of berberine, a natural product from Chinese herbs. Anticancer Drugs 2009;20(9):757-69.

19. Sakai T, Ohno N, Sakai H, Hyuga T. Extraction-spectrophotometric determination of berberine in crude drugs by the formation of a new ion associate. Anal Sci 1991;7:39-43.

20. Fadhil S, Reza MH, Rouhollah G,Reza VR. Spectrophotometric determination of total alkaloids in Peganum harmala L. using bromocresol green. J Pharm 2010;4:275-8.

21. Debnath B, Uddin MD, Patari P, Das M, Maiti D, Manna K. Estimation of alkaloids and phenolics of five edible cucurbitaceous plants and their antibacterial activity. Int J Pharm Pharm Sci 2015;7(12):223-7.

22. Fazel S, Monsef H, Ghamooshi R, Verdian-Rizi M. Spectrophotometric determination of total alkaloids in some Iranian medicinal plants. Thai J Pharm Sci 2008;32:17-20.

23. Keum YS, Jeong WS, Kong AN. Chemoprevention byisothiocyanates and their underlying molecular signaling mechanisms. Mutat Res 2004;555(1-2):191-202.

24. Valko M, Leibfritz D, Moncol J, Cronin MT, Mazur M, Telser J. Free radicals and antioxidants in normal physiological functions and human disease. Int J Biochem Cell Biol 2007;39(1):44-84.

25. Yu S, Kong AN. Targeting carcinogen metabolism by dietary cancer preventive compounds. Curr Cancer Drug Targets 2007;7(5):416-24.

26. Sharma R, Chandan G, Chahal A, Saini RV. Antioxidant and anticancer activity of methanolic extract from Stephania elegans. Int J Pharm Pharm Sci 2017:9(2):245-9.

27. Saleh MR, Al-Ataby SM, Al-Samarray YS. The cytotoxicity effect of ethanolic crude extract of Cnicus benedictus L. leaves on the murine mammary adencarcinoma cell line AMN-3. Iraqi J Cancer Med Genet 2015;8(1):72-8.

28. Haris M, Mahmood R, Rahman H, Rahman N. In vitro cytotoxic activity of Clerodendrum infortunatum L. Against T47D, PC-3, A549 and HCT-116 human cancer cell lines and its phytochemical screening. Int J Pharm Pharm Sci 2016;8:439-44.

29. Lu JJ, Bao JL, Chen XP, Huang M, Wang YT. Alkaloids isolated from natural herbs as the anticancer agents. Evid Based Complement Alternat Med 2012;2012:12.

30. Dogra RK, Khanna S, Shanker R. Immunotoxicological effects of piperine in mice. Toxicology 2004;196:229-36.

31. Unchern S, Saito H, Nishiyama N. Selective cytotoxicity of piperine on cultured rat hippocampal neurons in comparison with cultured astrocytes: The possible involvement of lipid peroxidation. Biol Pharm Bull 1997;20(9):958-61.

32. Choy CS, Cheah KP, Chiou HY, Li JS, Liu YH, Yong SF, et al. Induction of hepatotoxicity by sanguinarine is associated with oxidation of protein thiols and disturbance of mitochondrial respiration. J Appl Toxicol 2008;28(8):945-56.

33. Chan WH. Embryonic toxicity of sanguinarine through apoptotic processes in mouse blastocysts. Toxicol Lett 2011;205(3):285-92. 